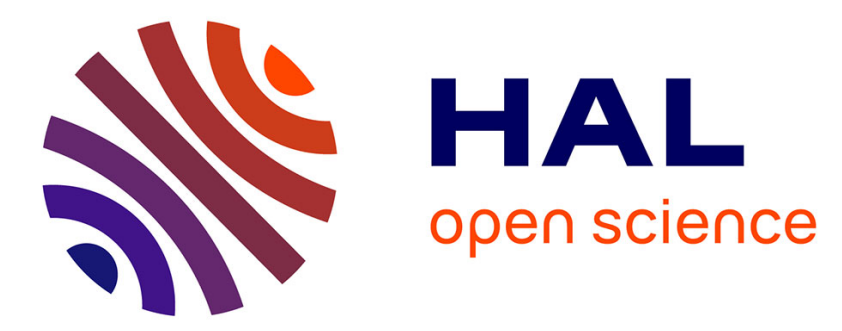

\title{
The use of a kinetic biomarker approach for in situ monitoring of littoral sediments using the crab Carcinus maenas
}

M. Laura Martín-Díaz, Julián Blasco, Diego Sales, T. Ángel Delvalls

\section{- To cite this version:}

M. Laura Martín-Díaz, Julián Blasco, Diego Sales, T. Ángel Delvalls. The use of a kinetic biomarker approach for in situ monitoring of littoral sediments using the crab Carcinus maenas. Marine Environmental Research, 2009, 68 (2), pp.82. 10.1016/j.marenvres.2009.04.005 . hal-00491628

\section{HAL Id: hal-00491628 \\ https://hal.science/hal-00491628}

Submitted on 14 Jun 2010

HAL is a multi-disciplinary open access archive for the deposit and dissemination of scientific research documents, whether they are published or not. The documents may come from teaching and research institutions in France or abroad, or from public or private research centers.
L'archive ouverte pluridisciplinaire HAL, est destinée au dépôt et à la diffusion de documents scientifiques de niveau recherche, publiés ou non, émanant des établissements d'enseignement et de recherche français ou étrangers, des laboratoires publics ou privés. 


\section{Accepted Manuscript}

The use of a kinetic biomarker approach for in situ monitoring of littoral sediments using the crab Carcinus maenas

M. Laura Martín-Díaz, Julián Blasco, Diego Sales, T. Ángel DelValls

PII:

S0141-1136(09)00040-3

DOI:

10.1016/j.marenvres.2009.04.005

Reference:

MERE 3333

To appear in:

Marine Environmental Research

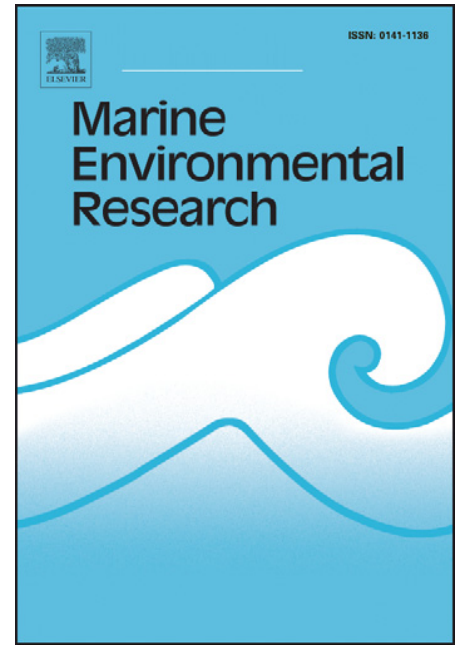

Received Date: $\quad 18$ November 2007

Revised Date: $\quad 5$ February 2009

Accepted Date: $\quad 10$ April 2009

Please cite this article as: Martín-Díaz, M.L., Blasco, J., Sales, D., DelValls, T.., The use of a kinetic biomarker approach for in situ monitoring of littoral sediments using the crab Carcinus maenas, Marine Environmental Research (2009), doi: 10.1016/j.marenvres.2009.04.005

This is a PDF file of an unedited manuscript that has been accepted for publication. As a service to our customers we are providing this early version of the manuscript. The manuscript will undergo copyediting, typesetting, and review of the resulting proof before it is published in its final form. Please note that during the production process errors may be discovered which could affect the content, and all legal disclaimers that apply to the journal pertain. 
3

4

5

6

$7 \quad{ }^{1}$ Consejo Superior de Investigaciones Científicas (CSIC). Instituto de Ciencias Marinas de Andalucía

8 (ICMAN). Polígono Río San Pedro s/n. 11510 Puerto Real. Cádiz. Spain.

9 2Universidad de Cádiz. Facultad de Ciencias del Mar y Ambientales. Departamento de Química Física.

10 Facultad de Ciencias del Mar y Ambientales. Polígono Río San Pedro s/n. 11510 Puerto Real. Cádiz. Spain.

11 3Departamento de Ingeniería Química, Tecnología de Alimentos y Tecnologías del Medio Ambiente. Facultad

12 de Ciencias del Mar y Ambientales. Polígono Río San Pedro s/n. 11510 Puerto Real. Cádiz. Spain.

19 *Corresponding author: M. Laura Martín Díaz

Phone:+34 956016423

21 Fax: +34 956016040

22 E-mail address: laura.martin@uca.es 


\section{Abstract}

24 Caged, transplanted, intermoult, female shore crabs (C. Maenas) were exposed to sediments from

25 the Port of Cadiz (SW, Spain); the Port of Huelva (SW, Spain), the Port of Pasajes (NE, Spain) and

26 the Port of Bilbao (NW, Spain) for a period of 28 days.

27 Organisms were sampled on days $0,7,14,21$ and 28 allowing examination of different biomarkers

28 to exposure to metals and organic compounds; Metallothioneins (MTs), Ethoxyresorufin O-

29 deethylase (EROD), Glutathione-S-transferase (GST) and Glutathione peroxidase (GPX). Sediment

30 samples were also analyzed to determine chemical concentration of metals ( $\mathrm{As}, \mathrm{Cd}, \mathrm{Cr}, \mathrm{Cu}, \mathrm{Hg}, \mathrm{Mn}$,

$31 \mathrm{Ni}, \mathrm{Pb}$ and $\mathrm{Zn}), \mathrm{PAHs}$ and PCBs.

32 Metals such as As, Cu and $\mathrm{Zn}$ associated with mining activities (Port of Huelva), and contaminants

33 such as $\mathrm{Ni}, \mathrm{Pb}, \mathrm{Hg}$ and PCBs, associated with oil spills and industrial activities (Ports of Cadiz,

34 Pasajes and Bilbao), were found to interfere in detoxification and/or anti-stress oxidative defenses in

35 C. maenas. Positive, significant $(p<0.05)$ induction of MTs concentration was associated with

36 increasing sediment $\mathrm{As}, \mathrm{Cu}, \mathrm{Zn}$ and $\mathrm{Hg}$ concentrations. EROD activity was associated with PCBs,

37 GST activity with $\mathrm{Hg}$ and GPX activity with $\mathrm{As}, \mathrm{Cu}, \mathrm{Ni}, \mathrm{Pb}$ and $\mathrm{Zn}$. The use of the parameter AR,

38 which involves the kinetic patterns of the battery of biomarkers tested, was found to be a powerful

39 and sensitive tool for evaluating the bioavailability and adverse effects of contaminants bound to

40 sediments, enabling polluted and non polluted sites to be easily distinguished.

41

43 Keywords: Metallothionein; Enzymatic activity; Oxidative stress; Carcinus maenas; Ecotoxicology;

44 Dredged material; Invertebrates. 


\section{Introduction}

47 Contaminated sediments are a risk to aquatic life, human health, and wildlife throughout the world.

48 Overwhelming evidence demonstrates that chemicals in sediments are responsible for toxicological

49 and adverse ecological effects (Andersen et al., 1998). Frequently, the chemicals causing these effects are present in the sediment as mixtures of organic, metal, and other types of compounds.

51 The adverse environmental effects associated with contaminated sediments in ports and estuaries

52 have resulted in a number of international treaties and protocols for their environmental 53 management. The OSPAR and Helsinki Conventions (North Sea, North-East Atlantic, Baltic Sea)

54 propose strict guidelines to control the disposal of contaminated sediments. In recent years, remediation and management of contaminated sediments is becoming increasingly important, which has led to an increasing economical and technological burden on management agencies. Thus, there is a clear need for the development of science based tools for the identification of sediments that are impaired, allowing agencies to set priorities and make effective management decisions for

59 dealing with contaminated sediments.

60 The most widely applied methods for the assessment of sediment toxicity are acute and chronic 61 sediment bioassays. Although a wide range of acute toxicity tests are already recommended, 62 standardized and included in sediment assessment regulatory frameworks, the development and 63 application of chronic toxicity tests including the measurement of sub lethal responses (biomarkers), 64 although widely supported, is still under investigation. The use of biomarkers in the evaluation of the 65 toxicity of dredged material is under continuous development and improvements are still desirable.

66 An important advantage of biomarkers in assessing the impact of dredged materials is their inherent 67 capability to detect the early occurrence of various stress conditions within the organism and monitor 68 the temporal progression (or regression) of the disturbance at various levels of biological 69 organization (Regoli et al., 2002). When assessing the exposure to a mixture of contaminants in dredged materials within the aquatic environment, biotransformation and antioxidant enzymes as 
71 well as metal-binding proteins such as metallothioneins (MTs) play an important role in identifying

72 contamination by organic and metal pollutants respectively. However, ecotoxicological

73 measurements obtained in laboratory studies can be difficult to translate into accurate predictions of

74 toxicological effects in the natural environment. Since both overestimation and underestimation of

75 effects may occur, laboratory observations must always be validated with field research. The

76 transplanting and caging of bioindicator organisms provides a combination of the experimental

77 control of laboratory bioassays and the environmental realism of field monitoring (Salazar and

78 Salazar, 1997). Thus, the combination of this methodology with biomarker measurements of suitable

79 indicator species may provide a strong tool for the monitoring of contaminated sediments, allowing

80 the determination of the total external load that is biologically available in the "real world" situation

81 (van der Oost et al., 2003).

82 Still, studies that use biotransformation and antioxidant enzymes as tools to monitor polluted sites

83 should be performed carefully. Various authors have pointed out the serious risk of misinterpretation

84 associated with using a single "snap-shot" (i.e., a single measurement at the end of exposure) to

85 rationalize oxidizing versus other effects of toxic contaminants in the environment (Bouskill et al.,

86 2006). Thus, a study of a continuous series of biomarker responses over time rather than a single

87 measurement after concrete exposure time should be performed in order to overcome the problem

88 mentioned above.

89 The aims of this study were to determine the measured biomarker responses within $C$. maenas over

90 a 28-day exposure period to contaminated sediments. This protocol was chosen to: 1) fill the lack

91 that exists from measuring a single time point,, 2) reveal temporal variation in oxidative injury related

92 to increasing exposure time, and 3) allow the distinction and classification of sites with different

93 magnitudes (and types) of sediment toxicity. To do this caged, female crabs were exposed in situ to

94 sediments with different levels of metals and organic compounds from a number ports within Spain.

95 The responses of a suite of biomarkers, including metallothioneins (MTs), mixed function oxidase 
96 (EROD), glutathione-S-tranferase (GST), and glutathione peroxidase (GPX): antioxidant enzyme

97 were determined during a 28-day exposure period and through a kinetic approach.

98

99

\section{Materials And Methods}

100

\subsection{Study site}

101 Eight sampling sites were chosen (Figure 1) for the assessment of sediment toxicity in Spanish ports.

102 Ca2 and Ca3 (negative toxicity control) were situated in the Port of Cádiz (SW, Spain), which has

103 been studied in some depth (DelValls et al., 1998; Riba et al., 2004a,b) and is characterized by an

104 absence of significant contamination. Hu2 and Hu3 were situated in the Port of Huelva (SW, Spain)

105 and are characterized by extensive heavy metal contamination related to historic mining activity. Bi2

106 and Bi3 were situated in the Port of Bilbao (NNE, Spain), which is characterized by significant

107 shipping activity with sediment contamination predominantly associated with organic contamination,

108 especially hydrocarbons. Pa2 and Pa3 were situated in the Port of Pasajes (NNE, Spain), which is

109 also characterized by significant shipping activity and by contamination associated with organic

110 compounds similar to the Port of Bilbao.

111

112 2.2. General approach

\section{2.2.1. Chemical characterization of the sediment}

114 Analysis of sediment was performed before starting the experiment according to Spanish

115 recommendations for dredged material (CEDEX, 1994). The dry weight fraction was measured using

116 the weight loss at $105^{\circ} \mathrm{C}$. In order to perform the rest of the analyses sediments were dried at $40^{\circ} \mathrm{C}$

117 over 24h. Metal content in the different sediments was determined following the methods reported

118 by Riba et al. (2004a,b); PCBs (congeners \#28, 52. 101, 118, 138, 153 and 180) and PAHs content

119 was analyzed according to U.S. EPA SW-846 method 8270/8082. All the analytical procedures were 
120 checked using reference material (MESS-1 NRC and CRM 277 BCR, for heavy metals and NCR-

121 CNRC HS-1 for organic compounds).

122

$123 \quad$ 2.2.2. In situ toxicity test

124 Intermoult, female, C. maenas of a standardized size (Martín-Diaz et al., 2004) were enclosed in

125 rectangular cages $(50 \times 25 \times 10 \mathrm{~cm})$ made of plastic net. During the experiment 24 crabs were

126 placed in each cage and 2 cages were placed per site. Crabs were fed frozen mussels. No condition

127 indexes were noted along the experiment. Low mortality was observed in individuals exposed to

128 control sediments which indicated that crabs conditions were feasible for field caging experiments.

129 The cages were anchored to the sediment at each site by a scuba-diver within each of the four

130 Spanish ports: Port of Cadiz (SW, Spain) (Ca2, Ca3-control sediment), Port of Huelva (SW, Spain)

131 (Hu2, Hu3), Port of Pasajes (NE, Spain) (Pa2, Pa3) and Port of Bilbao (NW, Spain) (Bi3, Bi2).

132 Cages were exposed to sediments for 28 days. On days $0,7,14,21$ and 28, cages were collected

133 and 10 individuals sampled. The temperature $\left(15^{\circ} \mathrm{C} \pm 1^{\circ} \mathrm{C}\right), \mathrm{pH}(7.8-8.2)$, salinity $(33.8 \pm 0.3)$ and

134 dissolved oxygen (>5 mg.L-1, $60 \%$ saturation) were measured.

135

$136 \quad$ 2.2.3. Sublethal responses determination

137 Ten, intermoult, female C. maenas were collected from within each port on days $0,7,14,21$ and 28.

138 Crabs were dissected and their hepatopancreas were removed for biomarker determination.

139 Hepatopancreas tissues were homogenized 1:4 in cold homogenization buffer: Hepes- $\mathrm{NaOH}(10$

$140 \mathrm{mM}$ ) buffer containing $125 \mathrm{mM} \mathrm{NaCl}, 1 \mathrm{mM}$ EDTA and $1 \mathrm{mM}$ dithiothreitol, $\mathrm{pH} 7.4$ at $4^{\circ} \mathrm{C}$ at a $1: 5$

141 weight:volume ratio (Lafontaine et al. 2000). After homogenization, samples were centrifuged $\left(4^{\circ} \mathrm{C}\right.$,

$14210000 \mathrm{~g}, 30 \mathrm{~min}$ ) and the supernatant collected for biomarker determination (S9 fraction). Samples

143 obtained to determine MTs content were centrifuged at $28000 \mathrm{~g}$ for $40 \mathrm{~min}$. The supernatant was

144 utilized for total protein determination according the dye-binding principle (Bradford, 1976). 
145 Metallothionein (MT) concentration in hepatopancreas tissues was determined by Anodic Stripping

146 Voltammetry (ASV) (Olafson and Olsson 1987). In brief, $0.1 \mathrm{~mL}$ of the supernatant (homogenate 28

$147000 \mathrm{~g}$ for $40 \mathrm{~min})$ was added to $0.9 \mathrm{~mL}$ of $\mathrm{NaCl}(0.9 \%)$, heated to $95^{\circ} \mathrm{C}$ for $4 \mathrm{~min}$, then centrifuged

148 at $10000 \mathrm{~g}$ for $15 \mathrm{~min}$ at $4^{\circ} \mathrm{C}$. The supernatant was stored at $-80^{\circ} \mathrm{C}$ prior to MT concentration

149 determinations using purified rabbit metallothionein (Sigma-Aldrich). MT concentrations were

150 expressed as $\mu \mathrm{g}$ MT (mg total protein)-1. Mixed function oxidize activity was measured using the 151 adapted EROD assay initially adapted for fingerling rainbow trout (Gagné and Blaise, 1993). $50 \mu \mathrm{L}$

152 of supernatant (homogenate $10000 \mathrm{~g}$ for $30 \mathrm{~min}$ ) were added to $10 \mu \mathrm{M}$ 7-ethoxyresorufin and 10

$153 \mu \mathrm{M}$ reduced $\mathrm{NADPH}$ in $100 \mathrm{mM} \mathrm{KH}_{2} \mathrm{PO}_{4}$ buffer $(\mathrm{pH}$ 7.4). The reaction was started by the addition of

$154 \mathrm{NADPH}$, allowed to proceed for $60 \mathrm{~min}$ at $30^{\circ} \mathrm{C}$, and stopped by the addition of $100 \mu \mathrm{L}$ of $0.1 \mathrm{M}$

$155 \mathrm{NaOH}$. The formation of 7-hydroxyresorufin was determined fluorometrically using $520 \mathrm{~nm}$

156 (excitation) and $590 \mathrm{~nm}$ (emission) filters. 7-hydroxyresorufin in the samples was achieved through a

157 standard calibration curve developed with concentrations of 7-hydroxyresorufin. Results were

158 expressed as $\mathrm{pmol} \cdot \mathrm{min}^{-1} \cdot\left(\mathrm{mg}\right.$ total protein) ${ }^{-1}$. The procedure utilized for the determination of

159 Glutathione S-transferase activity was adapted from the method of McFarland et al. (1999). The 160 activity was analyzed using $42 \mathrm{mM}$ 1-chloro-2,4-dinitrobenzene (CDNB) and $1 \mathrm{mM}$ GSH as

161 substrates and measured spectrophotometrically at $340 \mathrm{~nm}$ every 30 seconds for $3 \mathrm{~min}$. Results

162 were expressed as $\mathrm{nmol} \mathrm{min}^{-1}$ (mg total protein)-1. The methodology used for the determination of

163 glutathione peroxidase activity was also adapted from McFarland et al. (1999). GPX activities were

164 measured spectrophotometrically at $340 \mathrm{~nm}$ every 2 minutes for 10 minutes, using as substrate 1

$165 \mathrm{mM}$ cumene hydroperoxide. Results were expressed as nmol min-1 (mg total protein)-1.

166

167 2.3. Data and statistical analysis

168 A continuous study of biomarker responses over time as opposed to a measurement of sublethal 169 responses at a single time point was performed. Metallothioneins and enzymatic activity responses 
170 were fitted to different kinetic models using SIGMA PLOT 8.0 software package. Linear regression

171 was used to determine the kinetic parameters of MTs at each site. GST 's, EROD's and GPX's

172 kinetic equations were obtained through hyperbolic regression analysis, where the different

173 enzymatic activities were fitted to the best hyperbola equation.

174 In order to summarize the temporal variation of the different biomarkers, the area (AR) under the

175 fitted kinetic curves was calculated using Mathematica 4.0 Differences between the AR of control and

176 contaminated sediments were analyzed using SPSS/PC+. Significant differences between biomarker

177 responses of crabs exposed to control and contaminated sediments were determined using one-way

178 ANOVA. Post-hoc examination of significant differences between sites was carried out using

179 Dunett's test. The significance level was set at $p<0.01$.

180 Significant correlations between chemical concentrations in sediments and biomarker responses

181 (using AR parameters) were examined using a Pearson's correlation analysis using the SPSS/PC+

182 statistical package. The level of significance was set at $p<0.01$.

183

184 3. Results

185 3.1. Chemical characterization

186 Summarized results of the chemical analysis are shown in Table 1. The chemical characterization of

187 the sediment samples indicates that the sediments contain a mixture of contaminants (metals, PCBs

188 and PAHs). Sediments from the port of Huelva were characterized by higher concentrations of metals

189 (As, $\mathrm{Cu}, \mathrm{Pb}, \mathrm{Zn}, \mathrm{Ni}$ and $\mathrm{Cd}$ ) compared with the reference site $\mathrm{Ca}$. Whereas, sediments from the

190 ports of Pasajes and Bilbao were mostly characterized by high concentrations of PCBs and PAHs,

191 although contamination by metals such as $\mathrm{Cr}, \mathrm{Mn}, \mathrm{Ni}, \mathrm{Pb}$ and $\mathrm{Hg}$ was also found. Sediment from the

192 port of Cadiz was not highly contaminated (Ca3), although high concentrations of $\mathrm{Hg}$ were 193 determined in Ca2. 
$195 \quad$ 3.2. Specimen survival

196 During the 28-day, in situ, bioassay exposure to sediments from four Spanish ports, no sediment-

197 dependent mortalities were observed for intermoult female C. maenas. Survival in all treatments was 198 more than $90 \%$.

\subsection{Biomarker responses}

201 Summarized results of biomarker responses determined in hepatopancreas tissues of C. maenas 202 exposed to contaminated sediments ( $\mathrm{Ca} 2, \mathrm{Ca} 3, \mathrm{Hu} 2, \mathrm{Hu} 3, \mathrm{Bi} 2, \mathrm{Bi} 3, \mathrm{~Pa} 2, \mathrm{~Pa} 3$ ) are shown in Figure 203 2. In this figure experimental biomarker responses over time and their approximation to kinetic 204 models could be observed. Biomarker responses described different patterns over time for each 205 biomarker response measured in C. maenas. GST and GPX activities increased until days 14 and

20621 , respectively, after which they declined reaching basal levels by the end of the experiment. 207 EROD activity and MTs concentration increased during the 28-day exposure; with linear induction 208 observed for MTs and exponential induction for EROD activity. No significant induction of 209 detoxification and antioxidant parameters was observed in the control individuals (Ca3).

210 The equations to the different biomarkers, the correlation coefficient and the representation of the 211 areas (AR) calculated for each biomarker and sites are shown in Figure 3. The results show a good 212 correlation between the experimental data and those predicted by the results as described in Figure

213 2. It confirms a good approximation of biomarker induction (MTs, GPX, GST and EROD) to Linear 214 and Hyperbolic Kinetic models.

215 Significant induction of GST activity (compared to controls) were observed in crabs exposed to Ca2 216 (2.38\% of control) (p<0.01), Pa3 (1.70\%) (p<0.01), Bi2 (1.68\%) ( $p<0.01)$, Hu3 (1.45\%), Hu2 (1.40\%)

217 Bi3 (1.27\%) and Pa2 (1.12\%). Conversely, significant induction of GPX activity was also observed in 218 crabs exposed to Bi3 (16.75\% of control) ( $p<0.01)$, Pa3 (15.08\%) $(p<0.01)$, Hu2 (14.32\%) $(p<0.01)$, 219 Hu3 (14.07\%) (p<0.01), Bi2 (12.02\%) (p<0.01), Pa2 (10.85\%) $(\mathrm{p}<0.01)$ and Ca2 (9.38\%) $(\mathrm{P}<0.01)$. 
220 Significant induction of EROD activity in crabs exposed to Pa3 (16.71.52\% of control) $(\mathrm{p}<0.01), \mathrm{Pa} 2$

$221(1.47 \%)(P<0.01), B i 2(1.34 \%)(p<0.01), B i 3(1.19 \%)(p<0.05)$ and Ca2 (1.12\%) was also found. No

222 induction was observed in Hu2 and Hu3. Finally, significant MTs increase was observed in crabs

223 exposed to Hu3 (1.75\% of control) $(p<0.01)$, Hu2 (1.66\%) $(p<0.01)$, Ca2 $(1.45 \%) p<0.01)$, Bi2

224 (1.28\%), Pa3 (1.16\%). No induction in Bi3 and Pa2 was detected.

225 Significant positive correlations were observed between contaminants bound to sediments and

226 biomarker responses (Table 2). A significant correlation between GST activity induction and $\mathrm{Hg}(\mathrm{p}<$

$2270.05)$ was observed. Induction of GPX activity was correlated with $\mathrm{As}(\mathrm{p}<0.01), \mathrm{Cu}(\mathrm{p}<0.01), \mathrm{Pb}$

$228(p<0.01), \mathrm{Zn}(\mathrm{p}<0.01)$ and Ni $(p<0.01)$. Significant induction of EROD activity was only observed in

229 individuals exposed to $\sum$ PCBs. Whereas, MT induction was associated with the metals As $(p<0.05)$,

$230 \mathrm{Cd}(p<0.05), \mathrm{Cu}(\mathrm{p}<0.05), \mathrm{Zn}(\mathrm{p}<0.05)$ and $\mathrm{Hg}(\mathrm{p}<0.01)$.

231 The balance between bioactivation on the one hand and detoxication on the other can be crucial for

232 the assessment of possible hazards due to the exposure to toxic substances (van der Oost et al.

233 1998). For this reason, in the present study the biotransformation index (BTI) (van der Oost et al.,

234 1998), which is the ratio between phase I and phase II enzyme activities was determined (Figure 4).

235 EROD:GST in caged female crabs are maximally induced after 14 in Pa2, and after 21 days of

236 exposure in Ca2 and Pa3 (Figure 4). As opposed to the EROD activity, the BTI values in crabs

237 which belong to the mentioned sites decrease after 21 days of exposure due to the increased phase

238 II activities (Figure 4).

239

240 4. Discussion

241 Comparisons between the temporal biomarker responses in female crabs (C. maenas) exposed to

242 sediments from four Spanish ports and a new parameter, which involves biomarker responses over

243 time, have been calculated. This new parameter, AR, allowed the comparison of temporal biomarker 
244 responses in organisms exposed to control and contaminated sites, as well as contaminants bound

245 to sediment which have provoked adverse effects.

246

247 4.1. Metallothionein concentration (MT)

248 Significant induction $(\mathrm{p}<0.01)$ of MTs after 28-day exposure to sediments contaminated with As, Cd,

$249 \mathrm{Cu}, \mathrm{Hg}$ and $\mathrm{Zn}$ was found in $\mathrm{Hu} 2, \mathrm{Hu} 3$ and $\mathrm{Ca} 2(p<0.05)$. C. maenas has previously been shown to

250 be a useful species in metallothionein biomarker testing studies, allowing the detection of the

251 potential effects of metal contamination in situ (Bebianno et al. 2003). High concentrations of metals

252 were observed in the port of Huelva, presumably due to the historic mining activity in the area. Ca2

253 was also highly contaminated with $\mathrm{Hg}$. MTs constitute a family of low-molecular-weight, cysteine-rich

254 proteins functioning in the regulation of the essential metals $\mathrm{Cu}$ and $\mathrm{Zn}$, and in the detoxication of 255 these and other, non essential, metals such as $\mathrm{Cd}$ and $\mathrm{Hg}$ (Roesijadi and Robinson, 1994). The

256 cellular interactions involving MTs are expected to follow two general lines, the first being the

257 interception and binding of metal ions that are initially taken up by the cell and the second being the

258 removal of metals from nonthionein ligands that include cellular targets of toxicity. The latter may

259 represent a detoxication function for structures, which have been reversibly impaired by

260 inappropriate metal binding. The role of MTs in sequestering metals is well established, while their

261 induction by exposure to a wide variety of metals (e.g. $\mathrm{Cd}, \mathrm{Cu}, \mathrm{Zn}, \mathrm{Hg}, \mathrm{Co}, \mathrm{Ni}, \mathrm{Bi}$ and $\mathrm{Ag}$ ) is

262 associated with their induction by exposure protection function (Stegeman et al., 1992). Relatively

263 few studies in marine environments have reported the induction of MTs associated with As.

264 Nevertheless, induction of MTs due to As has been described in the freshwater invertebrate $D$.

265 polymorpha (Bauskill et al., 2006).

266

267 4.2. Ethoxyresorufin-O-deethlylase activity (EROD) 
268 EROD activity is involved in the first phase of metabolism, unmasking or adding reactive functional

269 groups, which involve oxidation and reduction or hydrolysis (Goeptar et al., 1995). Induction is a clear

270 sign of CYP1A1 enzyme activity, which is among the many known cytochrome isoforms. Increases in

271 EROD activities have been reported in many species of invertebrates, including clam and crab

272 species, following exposure to organic trace pollutants (Lafontaine et al., 2000). In the present study

273 significant induction $(p<0.01)$ of EROD activity was measured in hepatopancreas homogenates of $C$.

274 maenas exposed to PCBs $(p<0.01)$ bound to sediments from the port of Pasajes $(P a 2, P a 3)$.

275

276 4.3. Gluthatione-S-transferase activity (GST)

277 Chemical compounds, such as heavy metals, are biotransformed to conjugates of reduced 278 glutathione (GSH). Conjugation with GSH is a very important detoxification pathway that is catalyzed

279 by the enzyme GST. A significant increase in GST activity was observed in crabs exposed to 280 sediments from Ca2 $(p<0.05)$ associated with the presence of $\mathrm{Hg}(p<0.01)$. This finding indicates that

$281 \mathrm{Hg}$ (at the concentrations found at site Ca2), induces GST activity in the hepatoprancreas of $\mathrm{C}$.

282 maenas and may be used to elucidate the redox-activity generaterated by the oxidative stress 283 produced by $\mathrm{Hg}$ (Elunalai et al. 2007).

284

285 4.4. Gluthatione peroxidase activity (GPX)

286 Many pollutants (or their metabolites) may elicit toxicity reactions related to oxidative stress. Oxygen 287 toxicity may act as a strong oxidant, capable of reacting with critical cellular macromolecules, possibly 288 leading to DNA damage and cell death. Defense systems that inhibit oxyradical formation include the 289 antioxidant enzymes such as glutathione peroxidase (GPX) (van der Oost et al., 2000). GPX activity 290 measured was significantly increased after exposure to sediments from sites Ca2, Ca3, Hu2, Hu3, $291 \mathrm{Bi2}, \mathrm{Bi3}, \mathrm{Pa} 2$ and Pa3. Interestingly, the induction of this biomarker ranged from $9.38 \%$ to $16.75 \%$ 292 over control. The induction of this biomarker was correlated with high concentrations of sediment- 
293 bound metals, such as, $\mathrm{As}, \mathrm{Cu}, \mathrm{Pb}, \mathrm{Ni}$ and $\mathrm{Zn}$. Previous reports have also found that As (Bouskill et

294 al., 2006), Cu (Sánchez et al., 2005), Ni (Tsangaris et al., 2006), Pb (Alves de Almeida et al., 2004)

295 and Zn (Elumalai et al., 2007) have the capacity to promote oxidative stress and modulates enzymatic

296 and non-enzymatic antioxidant expression within biological tissues.

297

\section{4.5. Integrated time-dependant biomarkers responses}

299 By using a battery of biomarkers to evaluate sediment toxicity over a 28-day period, we were able to

300 analyze the time dependent trends in the biochemical responses of $C$. maenas. According to

301 Bouskill et al. (2006), if the cellular effects of contaminants bound to sediment followed a simple

302 linear etiology over time, initial EROD and MTs induction should protect cells from injury, followed by

303 antioxidant enzymes induction, GST and GPX, to avoid oxidative stress and lipid peroxidation when

304 MTs or EROD are overwhelmed. However, the biomarker responses observed in this study did not

305 appear to follow this simple linear etiology. Determined biomarker responses vary over the 28-day

306 exposure time due to differences in the contaminant levels for each site. Metallothioneins and EROD

307 enzymatic activity were induced by $\mathrm{As}, \mathrm{Cd}, \mathrm{Cu}, \mathrm{Hg}, \mathrm{Zn}$ and PCBs, respectively. Since, for these

308 biomarkers, the highest responses were found on day 28 , their induction was slower than that of

309 GPX and GST activities. This behavior suggests that after the beginning of the exposure, antioxidant

310 enzymes such as GST and GPX were induced to avoid the oxidative stress caused by $\mathrm{As}, \mathrm{Hg}, \mathrm{Cu}$,

$311 \mathrm{Ni}, \mathrm{Pb}$ and $\mathrm{Zn}$, as found in previous studies. After the initial induction, a return of antioxidant

312 enzymes to basal levels, suggests that MTs detoxification mechanisms were involved in the

313 acclimation of $\mathrm{C}$. maenas to contamination by $\mathrm{As}, \mathrm{Cd}, \mathrm{Cu}, \mathrm{Hg}$ and $\mathrm{Zn}$. In contrast, PCB exposure (at

314 the concentration tested) did not produce significant oxidative stress.

315 The delay in the induction of MTs could be due to the sequestration of metals by MTs via the

316 displacement of $\mathrm{Zn}$, leading to a release of free $\mathrm{Zn}$ that, in turn, induces de novo MTs synthesis. 
317 Indeed, in previous studies of invertebrate species (Correia et al., 2002; Rigwood et al., 1998)

318 exposed to As, induction of MTs was not fast enough to prevent lipid peroxidation.

319 In the present study biomarker responses have been correlated with the contaminants measured in

320 the sediments. Contaminants determined in the sediments tested are those recommended for

321 dredged material characterization (CEDEX, 1994). Nevertheless, more studies should be performed

322 in this direction since other contaminants not measured and synergetic and/or antagonic effects have

323 not been determined and could have affected the results obtained.

324 The BTI values determined in crabs at the sites Pa2, Pa3 and $\mathrm{Ca2}$, indicate that the actual hazards of

325 environmental contaminants slightly decrease in time after an initial increase. These results support

326 those described by van der Oost et al. (1998) which were found in caged carps exposed to polluted 327 sites.

330 5. Conclusions

331 In summary, by examining the temporal evolution of a suite of biomarkers in the test organism $C$.

332 maenas, it was revealed that $\mathrm{As}, \mathrm{Cu}$ and $\mathrm{Zn}$ associated with mining activities and $\mathrm{Ni}, \mathrm{Pb}, \mathrm{Hg}$ and

333 PCBs, associated with oil spills and industrial activities, interfere in detoxification and/or anti-stress

334 oxidative defenses under field conditions, suggesting that these contaminants are likely to cause

335 adverse effects in wild populations of C. maenas.

336 Different behaviors of the biomarker responses were observed related to the time-dependant

337 induction of metallothioneins, phase I enzymes and phase II enzymes. It is of increasing demand

338 that the study of biomarker responses over time and the search of a parameter that involves this

339 temporal evolution be undertaken. By using the calculated parameter AR we were able to

340 summarize the temporal progression of the ecotoxicological responses, allowing the comparison

341 toxic contaminant bioavailability between polluted and non-polluted sites. Oxidative injury has a 
342 temporal progression, which must be considered when using biotransformation and antioxidant

343 enzymes as biomarkers of sediment toxicity. Thus, we recommend the use of biomarker assays that

344 specifically consider the temporal progression of ecotoxiological responses, as these will provide a

345 stronger basis for the identification of sediment toxicity, particularly when sediments contain a

346 mixture of contaminants.

347

348 Acknowledgements.

349 This research was funded by a grant from the Spanish Ministry for Education and Science (REN2002-

350 01699) and the Spanish Ministry for Development (BOE, 13-12-2002). L. M. was funded by the "Juan

351 de la Cierva Programme" (Spanish Ministry for Education and Science). This manuscript has been 352 English edited by Edward Morris PhD. 
353

354

355

356

357

358

359

360

361

362

363

364

365

366

367

368

369

370

371

372

373

374 Canesi, L., Viarengo, A., Leonzio, C., Fllippelli, M., Gallo, G., 1999. Heavy metals and glutathione

375

376

377

\section{References}

Andersen, B., Hunt, J., Phillups, B., Tudor, S., Fairey, R., Newman, J., Puckett, M., Stephenson, M., Long, E.R., and Tjeerdema R.S., 1998. Comparision of marine sediment toxicity test protocols for the amphipod Rhepoxonius abronius and the polychaete worm Nereis (Neanthes) arenaceodentata. Environmental Toxicology and Chemistry, 17, 859 - 866.

Alves de Almeida, E., Miyamoto, S., Dias Bainy, A.C., Gennari de Medeiros, M.H., Di Mascio, P., 2004. Protective effect of phospholipid hydroperoxide glutathione peroxidase (PHGPX) against lipid peroxidation in mussels Perna perna exposed to different metals. Marine Pollution Bulletin, 49, 386 392.

Bebianno, M.J., Serafim, M.A., 2003. Variation of metal and Metallothionein concentrations in a natural population of Ruditapes decussatus. Archives of Environmental Contamination and Toxicology, 44, 53 -66 .

Bouskill, N. J., Handy, R. D., Ford, T.E., Galloway, T.S., 2006. Differentiating copper and arsenic toxicity using biochemical biomarkers in Asellus aquaticus and Dreissena polymorpha. Ecotoxicology and Environmental Safety, 65, 342 - 349.

Bradford, M.B., 1976. Analytical Biochemistry, 72, 248 - 254. metabolism in mussel tissues. Aquatic Toxicology, 46 (1), 67 - 76.

CEDEX (Centro de Estudios y Experimentación de Obras Públicas), 1994. 
378 Correia, A.D., Lima, G., Costa, M.H., Livingstone, D.R., 2002. Studies on biomarkers of copper

379 exposure and toxicity in marine amphipod Gammarus lacusta (Crustacea): 1. Induction of 380 metallothionein and lipid peroxidation. Biomarkers 7, 422 - 437.

381

382 DelValls, T,A, Chapman, P.M., 1998. Site-specific sediment quality values for the Gulf of Cádiz 383 (Spain) and San Francisco Bay (USA), using the sediment quality triad and multivariate analysis. 384 Ciencias Marinas, 24, 3313 - 3336.

385

386 Elumalai, M., Antunes, C., Guillhermino, L., 2007. Enzymatic biomarkers in the crab Carcinus maenas 387 from Minho River estuary (NW Portugal) exposed to zinc and mercury. Chemosphere, 66, 1249 3881255.

389

390 Gagné, F., Blaise, C.,1993. Hepatic metallothionein level and mixed function oxidase activity in

391 fingerling rainbow trout (Oncorhynchus mykiss) after acute exposure to pulp and paper mill effluents 392 Water Research, 27, 1669 - 1682.

393

394 Goeptar, A.R., Scheerens, H., Vermeulen, N.P.E., 1995. Oxygen reductase and substrate reductase 395 activity of cytochrome P450. Critical Review in Toxicolology, 25, 25 - 65.

396

397 Hollis, L., Hogstrand, C., Wood, C.M., 2001. Tissue-specific cadmium accumulation, metallothionein 398 induction, and tissue zinc and copper levels during chronic sublethal exposure in juvenile rainbow 399 trout. Archives of Environmental Contamination and Toxicology, 41, 468 - 474. 
401 Lafontaine Y., Gagné, F., Blaise, C., Costan, G., Gagnon, P., Chan, H.M., 2000. Biomarkers in zebra

402 mussels (Dreissena polymorpha) for the assessment and monitoring of water quality of the St

403 Lawrence River (Canada). Aquatic Toxicology, 50, 51 - 70.

404

405 Martín-Díaz, M.L., Bamber, S., Casado-Martínez, M.C., Sales, D., DelValls, T.A., 2004. Toxicokinetic

406 of heavy metals from a mining spill using Carcinus maenas. Marine Environmental Research, 58, 833 $407-837$.

408

409 Martín-Díaz, M.L., Blasco, J., Sales, D., Del Valls, T.A., Field validation of a battery of biomarkers to assess sediment quality in Spanish ports. Environmental Pollution, in press.

411

412 McFarland, V.A., Inouye, S.L., Lutz, C.H., Jarvis, A.S., Clarke, J.U., McCant, D.D., 1999. Biomarkers

413 of oxidative stress and genotoxicity in livers of field collected brown bullhead, Ameiurus nebulosus.

414 Archives of Environmental Contamination and Toxicology, 37, 236 - 241.

415

416 Olafson, R.W., Olsson P.E., 1987. Electrochemical detection of metallothionein, zinc and copper 417 levels during an annual reproductive cycle in Rainbow trout (Salmo gairdneri). Fish Physiology and 418 Biochemistry, 31, $39-47$.

419

420 Regoli, F., Pellegrini D., Winston G.W., Gorbi, S., Giuliani, S., Virno-Lamberti, C., Bompadre, S., 421 2002. Marine Pollution Bulletin, 44, 912 - 922.

422

423 Riba, I., DelValls, T.A., Forja, J.M., Gómez-Parra, A., 2002. Influence of the Aznalcollar mining spill on 424 the vertical distribution of heavy metals in sediments from the Guadalquivir estuary (SW, Spain). 425 Marine Pollution Bulletin, 44, 39 - 47. 
427 Riba, I., Forja, J.M., Gómez-Parra, A., DelValls, T.A., 2004a. Sediment quality in littoral regions of the

428 Golf of Cádiz: a triad approach to address the influence of mining activities. Environmental Pollution, $429 \quad 132,341-353$.

430

431 Riba, I., Blasco, J., Jiménez-Tenorio, N., González de Canales, M.L., DelValls, T.A. 2004b. Heavy 432 metal bioavailability and effects: II. Histopathology-bioaccumulation relationships caused by mining 433 activities in the Gulf of Cádiz (SW, Spain). Chemosphere 58, 671 - 682.

434

435 Ringwood, A.H., Conners, D.E., DiNovo, A., 1998. The effects of copper exposures on cellular 436 responses in Oysters. Marine Environmental Research, 46, 591 - 595.

437

Roesijadi, G., Robinson, W.E., 1994. Metal regulation in aquatic animals: mechanisms of uptake, accumulation and release. In: Malins, D.C., Ostrander, G.K. (Eds.), Aquatic Toxicology; Molecular, Biochemical and Cellular Perspectives. Lewis Publishers, CRC press, pp. 387 - 420.

441

Roesijadi, G., 1996. Metallothionein and its role in toxic metal regulation. Comparative Biochemistry and Physiology Part C 113, 117 - 123.

444

Salazar, M.H., Salazar, S.M., 1997. Using caged bivalves to characterize exposure and effects associated with pulp and paper mill effluents. Water Science and Technology, 35 (2-3), 213 - 220.

448 Sanchez, W., Palluel, O., Meinier, L., Coquery, M., Porcher, J.M., Aït-Aïssa, S., 2005. Copper449 induced oxidative stress in three-spined stickleback: relationship with hepatic metal levels. 450 Environmental Toxicology and Pharmacology, 19, 177 - 183. 
452 Stegeman, J. J., Brouwer, M., Richard, T.D.G., Förlin, L., Fowler, B.A., Sanders, B.M., Van Veld, P.A.,

453 1992. Molecular responses to environmental contamination: enzyme and protein systems as indicators

454 of chemical exposure and effect. In: Huggett, R. J., Kimerly, R.A., Mehrle, P.M., Jr., Bergman, H.L.

455 (Eds.), Biomarkers: Biochemical, Physiological and Histological markers of Anthropogenic Stress.

456 Lewis Publishers, Chelsea, MI, USA, pp. 235 - 335.

457

458 Thiele, D.J., 1992. Metal-regulated transcription in eukaryotes. Nucl. Acids Res. 20, 1183 - 1188

459

460 Tsangaris, C., Papathanasiou, E., Cotou, E., 2007. Assessment of the impact of heavy metal pollution

461 from ferro-nickel smelting plant using biomarkers. Ecotoxicology and Environmental Safety, 66, 232 462243.

463

464 van der Oost, R., Lopes, S. C. C., Komen, H., Satumalay, K., van den Bos, R., Heida, H., Verrneuler, 465 V., 1998. Assessment of Environmental Quality and Inland Water Pollution Using Biomarker 466 Responses in Caged Carp (Cyprinus carpio): Use of a Bioactivation:detoxication Ratio as a 467 Biotransformation Index (BTI). Marine Environmental Reasearch, 46, 315 - 319.

468

469

van der Oost, R., Beyer, J., Vermeulen N.P.E., 2003. Fish bioaccumulation and biomarkers in environmental risk assessment. Environmental Toxicology and Pharmacology, 13, 57 - 149. 
478 Figure captions:

479 Figure 1. Localization of sampling points in the Iberian Peninsula.

480

481 Figure 2. Representation of metallothioneins (MTs) concentration, Ethoxyresorufin O-deethylase 482 (EROD), Glutathione-S-transferase (GST), Glutathione Reductase (GR) and Glutathione Peroxidase 483 (GPX) activities determined in hepatopancreas of Carcinus maenas over a 28-day exposure period to 484 sediments from the port of Cadiz (Ca2, Ca3), the port of Huelva (Hu2, Hu3), the port of Pasajes (Pa2, 485 Pa3) and the port of Bilbao (Bi2, Bi3).

486

487 Figure 3. Representation of the area under the curve (AR) calculated for each biomarker and 488 sediment. Results of correlation coefficient, $\mathrm{r}^{2}$ and fitted equation are also shown. Asterisks show significant differences of the AR with control sediment (Ca3) $\left({ }^{\star *} \mathrm{p}<0.01\right)$.

490

491 Figure 4. Biotransformation index: EROD : GST in C. maenas hepatopancres exposed over a 28-day 492 period to sediments from the ports of Cadiz (Ca2, Ca3), the port of Huelva (Hu2, Hu3), the port of 493 Pasajes (Pa2, Pa3) and the port of Bilbao (Bi2, Bi3). 


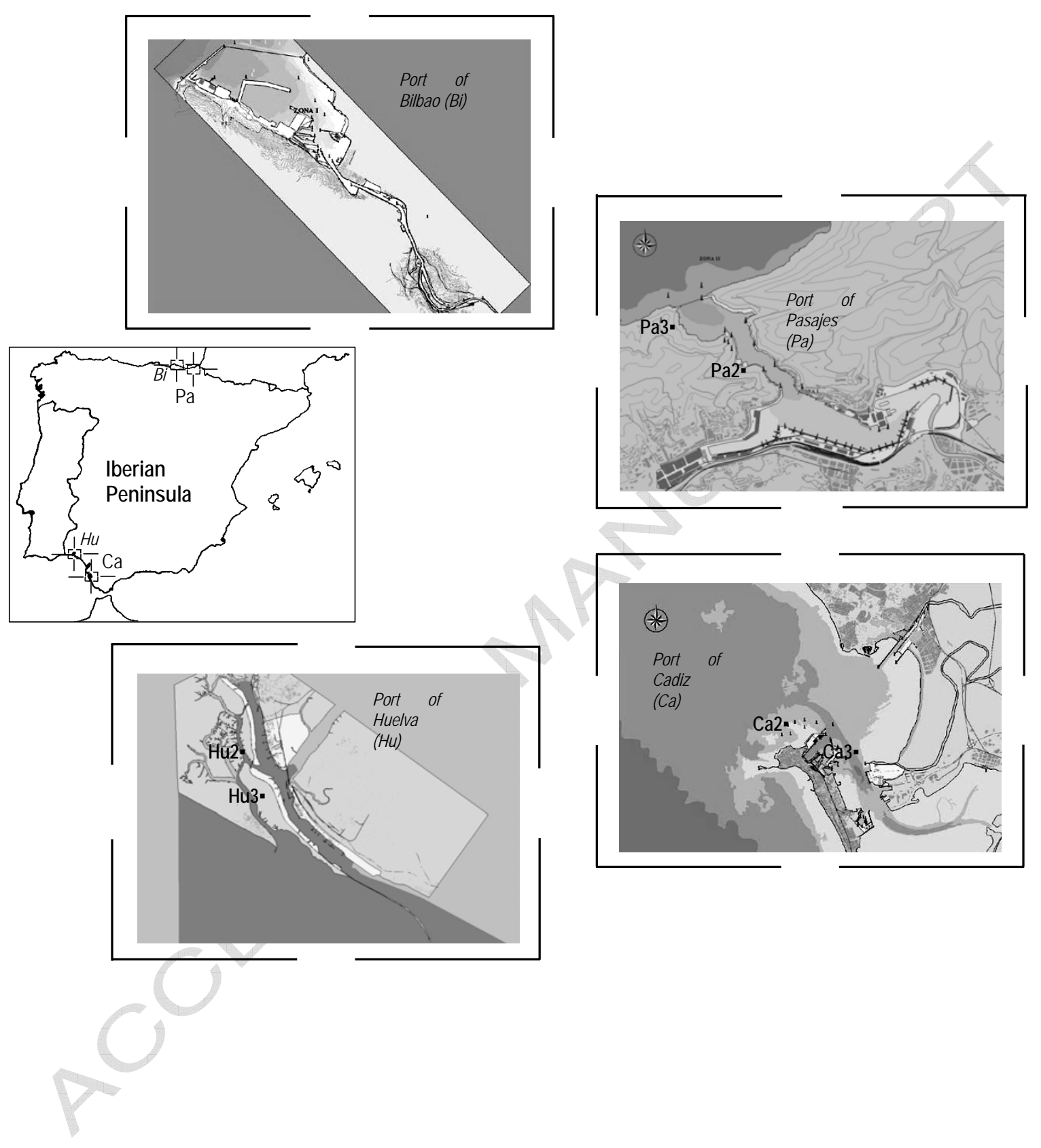



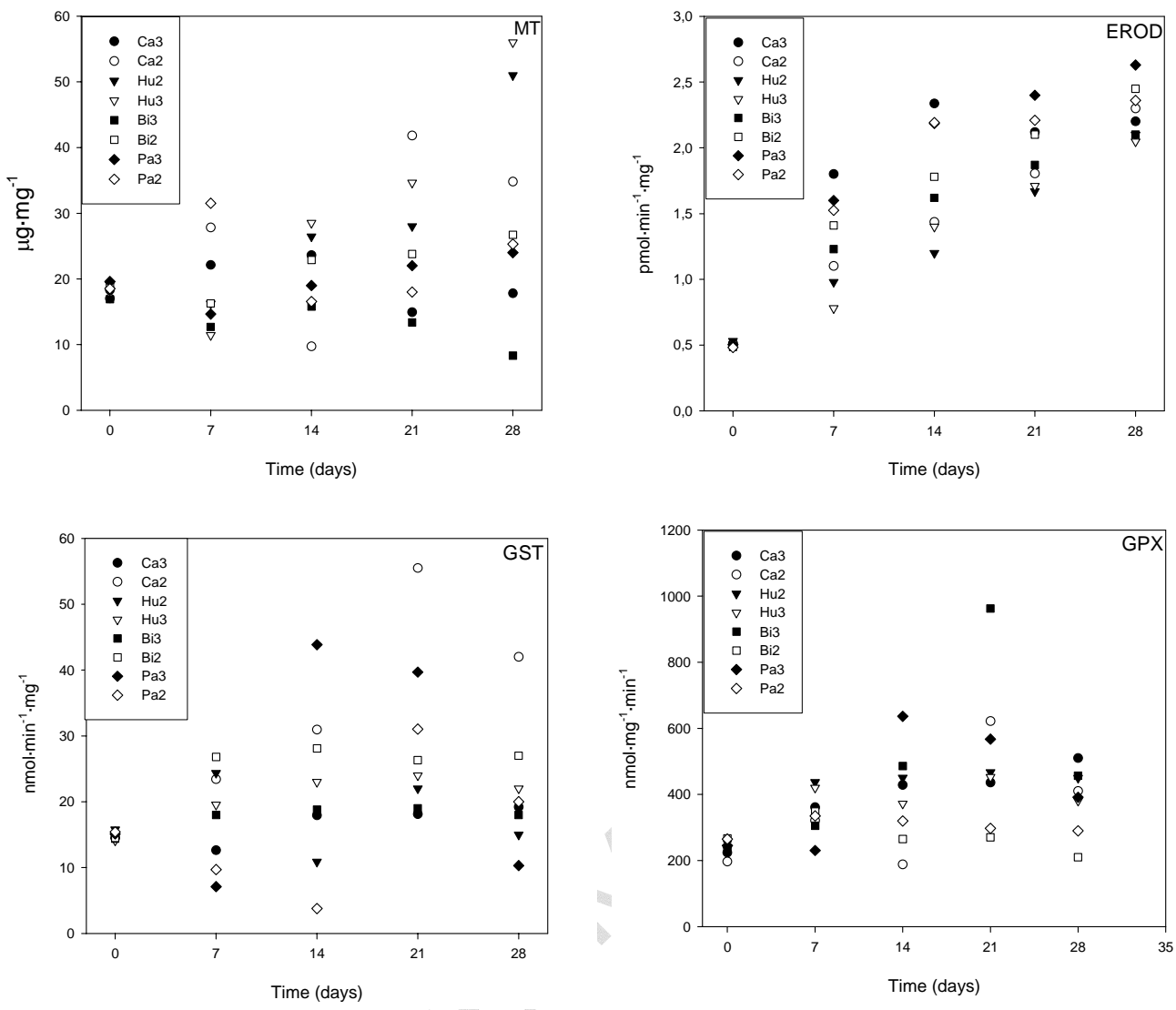


\section{2}

3

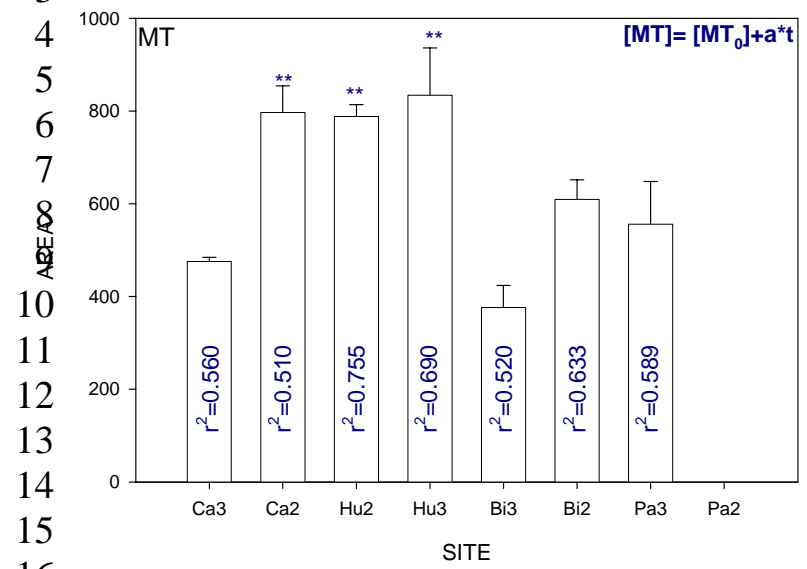

16

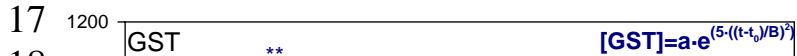

18

19

20

21

$2 \frac{5}{4}$

23

24

25

26

27

28

29

30

31

32

33

34

35

36

37

38

39

40

41

42

43

44
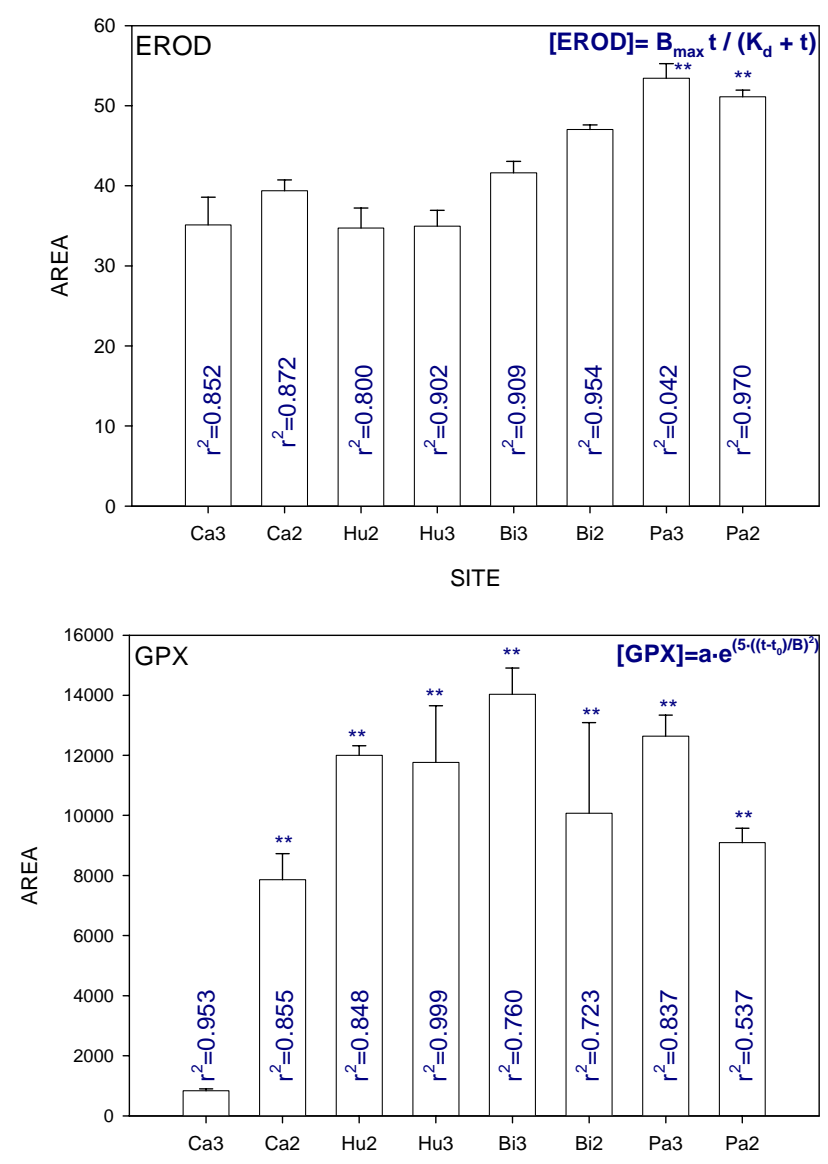
EROD : GST ratio

50

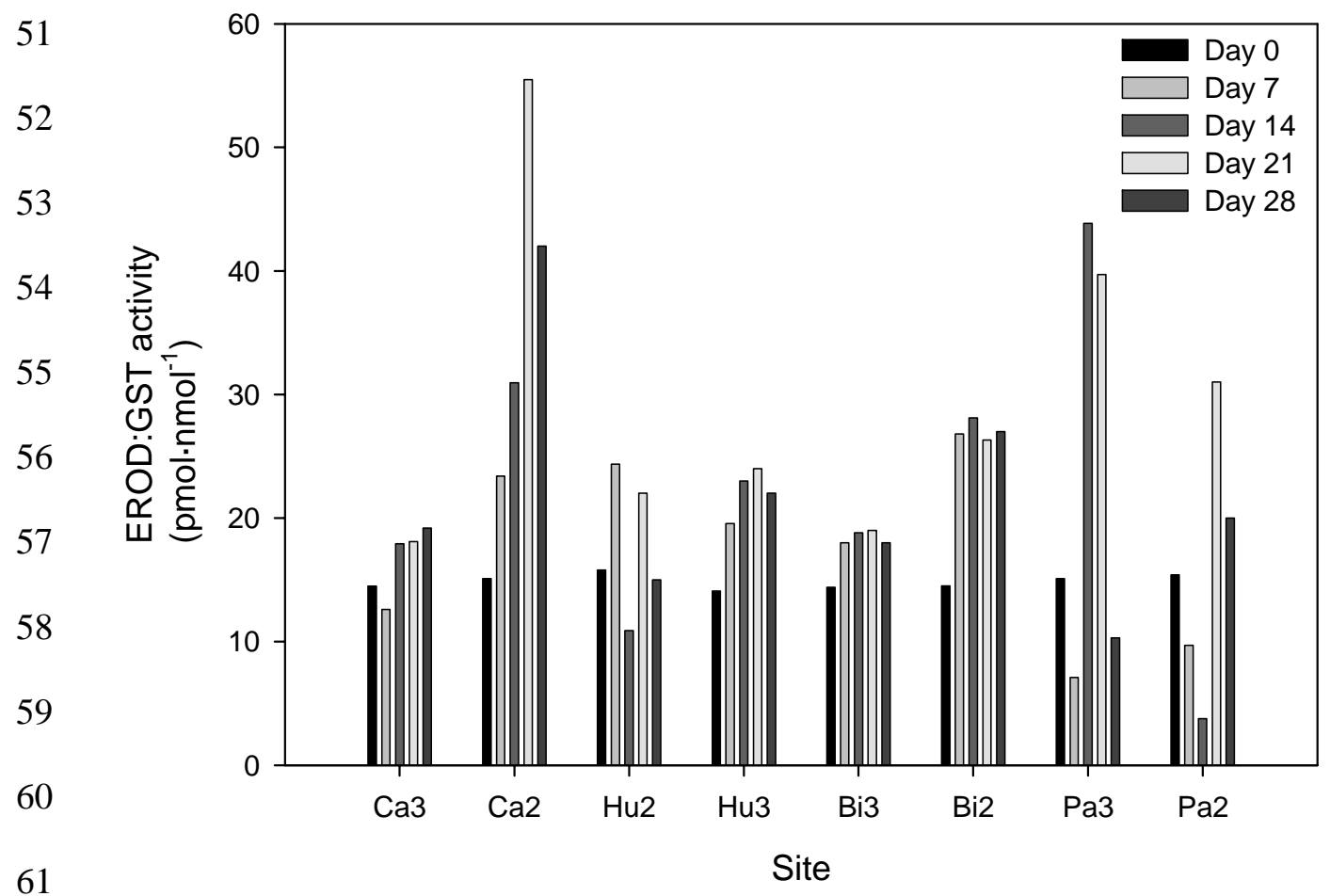

62

63

64

65

66

67

68

69

70

71 
73 Table 1. Summarized results of chemical concentrations of sediments from the Port of Cadiz (Ca2, 74 Ca3), Port of Huelva (Hu2, Hu3), Port of Bilbao (Bi2, Bi3) and Port of Pasajes (Pa2, Pa3). Chemical

\begin{tabular}{|c|c|c|c|c|c|c|c|c|c|c|c|}
\hline SITE & As & $\mathrm{Cd}$ & $\mathrm{Cr}$ & $\mathrm{Cu}$ & $\mathrm{Hg}$ & $\mathrm{Mn}$ & $\mathrm{Ni}$ & $\mathrm{Pb}$ & $\mathrm{Zn}$ & $\Sigma \mathrm{PCB}$ & $\begin{array}{c}\text { SPAHs } \\
76\end{array}$ \\
\hline$\overline{\text { CA2 }}$ & 30.77 & 1.32 & 14.94 & 202.80 & 1.98 & 201.60 & 20.14 & 86.90 & 378.25 & 0.11 & $\begin{array}{r}0.11 \\
77\end{array}$ \\
\hline CA3 & 16.61 & 1.23 & 8.43 & 46.76 & 0.28 & 294.40 & 16.90 & 17.61 & 135.50 & 0.01 & 0.01 \\
\hline HU2 & 532.27 & 2.50 & 24.10 & 149.70 & 1.99 & 303.60 & 7.10 & 384.70 & 1857.00 & .01 & $\begin{array}{r}0.01 \\
79\end{array}$ \\
\hline HU3 & 272.78 & 1.32 & 8.13 & 772.50 & 1.20 & 354.45 & 128.55 & 217.60 & 1176.00 & 0.01 & $\begin{array}{r}0.01 \\
80\end{array}$ \\
\hline $\mathrm{BI} 2$ & 104.49 & 2.00 & 23.11 & 204.10 & 1.43 & 396.60 & 32.00 & 147.50 & 777.50 & 0.23 & $\begin{array}{r}66.77 \\
81\end{array}$ \\
\hline $\mathrm{BI} 3$ & 21.71 & 0.04 & 3.48 & 23.03 & 0.18 & 191.35 & 15.72 & 285.90 & 122.35 & 0.01 & $\begin{array}{r}13.90 \\
82\end{array}$ \\
\hline PA2 & 28.76 & 0.70 & 23.42 & 167.10 & 1.29 & 180.00 & 28.48 & 293.70 & 763.00 & 0.74 & $\begin{array}{r}1.06 \\
83\end{array}$ \\
\hline РA3 & 23.78 & 0.04 & 18.61 & 162.50 & 1.36 & 152.60 & 19.61 & 246.00 & 576.00 & 0.24 & $\begin{array}{r}0.26 \\
84 \\
\end{array}$ \\
\hline
\end{tabular}

$85 \mathrm{~s}$ are expressed as $\mathrm{mg} \cdot \mathrm{kg}^{-1}$.

86 
87 Table 2. Significant positive Pearson's correlation between biomarkers responses and contaminants

88 of interest. Data were pooled across sites and areas (AR) of the fitted kinetic approaches. Asterisks

89 indicate significant relationships ( $\left.{ }^{*} p<0.05 ;{ }^{*} p<0.01\right)$.

90

\begin{tabular}{|c|c|c|c|c|}
\hline $\begin{array}{l}\text { Biomarker/ } \\
\text { Contaminant }\end{array}$ & GST & GPX & EROD & MT \\
\hline As & - & $0.48^{\star \star}$ & 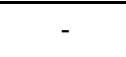 & $0.40^{*}$ \\
\hline $\mathrm{Cd}$ & 0.01 & 0.02 & - & $0.4^{*}$ \\
\hline $\mathrm{Cr}$ & 0.01 & 0.00 & 0.04 & 0.02 \\
\hline $\mathrm{Cu}$ & - & $0.46^{\star *}$ & - & $0.47^{*}$ \\
\hline $\mathrm{Hg}$ & $0.4^{\star}$ & 0.27 & - & $0.51^{\star \star}$ \\
\hline $\mathrm{Mn}$ & - & 0.15 & & 0.25 \\
\hline $\mathrm{Ni}$ & - & $0.42^{\star \star}$ & & 0.15 \\
\hline $\mathrm{Pb}$ & - & $0.69^{* *}$ & 0.25 & 0.23 \\
\hline $\mathrm{Zn}$ & & $0.52^{\star \star}$ & - & $0.4^{*}$ \\
\hline$\Sigma \mathrm{PCBS}$ & & 0.00 & $0.73^{\star *}$ & - \\
\hline$\Sigma \mathrm{PAHS}$ & 0.13 & 0.04 & 0.30 & 0.09 \\
\hline
\end{tabular}

91

92

93

94

95

96 